JURNAL PENGABDIAN PADA MASYARAKAT ISSN 2540-8739 (print) || ISSN 2540-8747 (online)

LEMBAGA PENELITIAN, PENGABDIAN, DAN PENGEMBANGAN MASYARAKAT UNIVERSITAS MATHLA'UL ANWAR BANTEN

\title{
Analisis Kesehatan Lingkungan Rumah, Penyuluhan dan Pelatihan Pencegahan Tuberkulosis (TB) di Bantul, Yogyakarta
}

\author{
Surahma Asti Mulasari ${ }^{1}$ \\ 1 Universitas Ahmad Dahlan
}

\begin{tabular}{|c|c|}
\hline Article History & ABSTRACT \\
\hline \multirow[t]{2}{*}{$\begin{array}{l}\text { Received 06.12.2018 } \\
\text { Received in revised form } \\
\text { 08.04.2019 } \\
\text { Accepted } 26.07 .2019 \\
\text { Available online } 20.08 .2019\end{array}$} & $\begin{array}{l}\text { HOME ENVIRONMENTAL HEALTH ANALYSIS, COUNSELING AND } \\
\text { TUBERCULOSIS PREVENTION TRAINING (TB) IN BANTUL, YOGYAKARTA. } \\
\text { Tuberculosis (TB) is an infectious disease caused by the bacterium Mycobacterium } \\
\text { tuberculosis, this disease can attack various organs, especially the lungs. This } \\
\text { disease, if left untreated or incomplete treatment, can cause dangerous } \\
\text { complications to death, and potential to spread to other people. In Hamlet "X" RT } \\
09 \text { Bantul Yogyakarta, there were families with Tuberculosis sufferers. The } \\
\text { purpose of this activity was to prevent the risk of TB transmission and increase } \\
\text { the knowledge of residents around TB patients at the service location. The method } \\
\text { used in this activity was to analyze the condition of the home environment } \\
\text { associated with TB, provide training in managing the home environment to be } \\
\text { healthy. The impact obtained was an increase in the knowledge of residents and } \\
\text { families of TB patients, and reduce the risk of transmission of TB in the home and } \\
\text { community environment. }\end{array}$ \\
\hline & KEYWORDS: Environmental Health, Knowledge, Prevention, Risk, TB. \\
\hline
\end{tabular}

DOI: $10.30653 / 002.201942 .97$

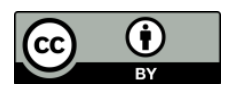

This is an open access article distributed under the terms of the Creative Commons Attribution 4.0 International License, which permits unrestricted use, distribution, and reproduction in any medium, provided the original work is properly cited. (c) 2019 Surahma Asti Mulasari.

\section{PENDAHULUAN}

Sasaran dari Program Indonesia Sehat adalah meningkatnya derajat kesehatan dan status gizi masyarakat melalui upaya kesehatan dan pemberdayaan masyarakat yang didukung dengan perlindungan finansial dan pemerataan pelayanan kesehatan. Satu keluarga adalah satu kesatuan keluarga inti (ayah, ibu, dan anak) sebagaimana dinyatakan dalam kartu keluarga. Keluarga yang terdapat kakek dan atau nenek atau individu lain dalam satu rumah tangga, maka rumah tangga tersebut dianggap terdiri lebih dari satu keluarga. Suatu keluarga dinyatakan sehat atau tidak digunakan beberapa penanda atau indikator. Dalam rangka pelaksanaaan Program Indonesia Sehat telah

${ }^{1}$ Corresponding author: Fakultas Kesehatan Masyarakat Universitas Ahmad Dahlan; Jl. Prof. DR. Soepomo Sh, Warungboto, Kec. Umbulharjo, Kota Yogyakarta, Daerah Istimewa Yogyakarta 55164, Indonesia; Email: surahma.mulasari@ikm.uad.ac.id 
disepakati adanya dua belas indikator utama untuk penanda status kesehatan sebuah keluarga. Kedua belas indikator utama tersebut adalah sebagai berikut: 1) Keluarga mengikuti program Keluarga Berencana (KB), 2) Ibu melakukan persalinan di fasilitas kesehatan, 3) Bayi mendapat imunisasi dasar lengkap, 4) Bayi mendapat air susu ibu (ASI) eksklusif, 5) Balita mendapatkan pematauan pertumbuhan, 6) Penderita tuberkulosis paru mendapatkan pengobatan sesuai standar, 7). Penderita hipertensi melakukan pengobatan secara teratur, 8) Penderita gangguan jiwa mendapatkan pengobatan dan tidak ditelantarkan, 9) Anggota keluarga tidak ada yang merokok, 10) Keluarga sudah menjadi anggota Jaminan Kesehatan Nasional (JKN), 11) Keluarga mempunyai akses sarana air bersih, 12) Keluarga mempunyai akses atau menggunakan jamban sehat (Kemenkes RI, 2015).

Berdasarkan indikator tersebut, dilakukan penghitungan Indeks Keluarga Sehat (IKS) dari setiap keluarga, sedangkan keadaan masing-masing indikator mencerminkan kondisi PHBS dari keluarga yang bersangkutan. Setelah pengambilah data yang telah kami lakukan di RT 09 X, didapatkan hasilnya bahwa terdapat keluarga yang penderita Tuberkulosis. Tuberkulosis (TB) adalah suatu penyakit infeksi menular yang disebabkan bakteri Mycobacterium tuberculosis, yang dapat menyerang berbagai organ, terutama paruparu. Penyakit ini bila tidak diobati atau pengobatannya tidak tuntas dapat menimbulkan komplikasi berbahaya hingga kematian. TB diperkirakan sudah ada di dunia sejak 5000 tahun sebelum masehi, namun kemajuan dalam penemuan dan pengendalian penyakit TB baru terjadi dalam 2 abad terakhir (Kemenkes RI, 2015).

Indonesia merupakan negara dengan jumlah kasus baru terbanyak kedua di dunia setelah India. Sebesar 60\% kasus baru terjadi di 6 negara yaitu India, Indonesia, China, Nigeria, Pakistan dan Afrika Selatan. Kematian akibat Tuberkulosis diperkirakan sebanyak 1,4 juta kematian ditambah 0,4 juta kematian akibat tuberkulosis pada orang dengan HIV. Meskipun jumlah kematian akibat Tuberkulosis menurun $22 \%$ antara tahun 2000 dan 2015, Tuberkulosis tetap menjadi 10 penyebab kematian tertinggi di dunia pada tahun 2015 (Kemenkes RI, 2017).

Di Provinsi Daerah Istimewa Yogyakarta jumlah kasus Tuberkulosis Paru Pada Tahun 2012 sebanyak 1566 kasus, dengan urutan tertinggi berada di Kabupaten Gunung Kidul 436 kasus, Kabupaten Bantul 416 kasus, Kabupaten Sleman 328 kasus, Kota Yogyakarta 268 kasus dan Kabupaten Kulon Progo 118 kasus. Jumlah kematian yang diakibat oleh Tuberkulosis Paru sebanyak 31 kasus, dimana yang paling tinggi berada di Kota Yogyakarta sebanyak 16 kasus (Dinas Kesehatan DI Yogyakarta, 2013).

Penemuan kasus TB BTA Positif di Kabupaten Bantul pada Tahun 2016 sebesar 34,89 $\%$ turun dibandingkan Tahun 2015 yang dilaporkan sebesar 66,80 \%. Jumlah kematian akibat TB dilaporkan sejumlah 13 orang. Angka kesuksesan (Success Rate) terdiri dari angka kesembuhan dan pengobatan lengkap TB Paru. Angka kesuksesan pada tahun 2016 dilaporkan sebesar 104,67 \%. Angka kesembuhan (Cure rate) pada tahun 2016 dilaporkan sebesar 100\%. Angka kesembuhan pengobatan TB di Kabupaten Bantul pada Tahun 2016 naik bila dibandingkan dengan tahun 2015 sebesar 82,19 dan angka kesembuhan ini juga berada di atas target Nasional (85\%). Penurunan angka kesembuhan ini merupakan dampak dari meningkatnya jenis kasus TB Multi Drug Resisten (MDR) (Dinkes Kabupaten Bantul, 2016). 
Berdasarkan latar belakang di atas, maka kami tertarik untuk melakukan intervensi masalah kesehatan yang ada di Dusun X RT 09 berdasarkan 12 Indikator PIS-PK dengan mengakat tema tuberculosis (TB) sesuai hasil community diagnosis di lapangan disesuaikan dengan program PIS-PK. Tujuan pengabdian ini untuk melakukan analisis kondisi lingkungan rumah penderita $\mathrm{TB}$, memberikan pelatihan anggota keluarga penderita $\mathrm{TB}$ untuk mewujudkan rumah sehat dan mencegah penularan lebih luas dan memberikan keterampila dalam mencegah penularan TB di lingkungan rumah serta memberika pengetahua tentang $\mathrm{TB}$, pencegahan dan penanggulangannya untuk masyarakat Dusun $X$ RT 09. Secara umum tujuan dari kegiatan ini adalah untuk mencegah resiko penularan TB dan meningkatkan pengetahuan warga masyarakat di sekitar penderita TB.

\section{METODE PELAKSANAAN}

Metode yang digunakan dalam kegiatan ini adalah dengan melakukan analisis kondisi lingkungan rumah terkait dengan $\mathrm{TB}$, memberikan pelatihan pengelolaan lingkungan rumah agar sehat, serta penyuluhan TB dan penanggulangannya. Materi yang diberikan berupa materi ceramah dan pelatihan sehingga peserta tidak hanya mendengarkan ceramah tetapi juga mendapatkan pelatihan dan ada pula kegiatan diskusi. Kegiatan pengabdian dilakukan bersama dengan mahasiswa FKM UAD untuk memberikan pengalaman langsung kepada mahasiswa dan sekaligus meningkatkan pemahaman dan frekuensi interaksi dosen-mahasiswa.

Materi yang disajikan dengan metode ceramah, berkaitan dengan penyakit TB, yaitu meliputi definisi, ciri-ciri, penyebab, cara pencegahan dan pengobatan penyakit. Peserta juga diberi leaflet mengenai penyakit TB dengan tujuan agar peserta pelatihan dapat lebih meningkatkan kemampuan dalam menyerap materi yang disampaikan oleh narasumber, selain itu peserta dapat membaca kembali materi penyuluhan di rumah, apabila peserta ada yang lupa mengenai materi penyuluhan yang sudah disampaikan sebelumnya.

Pelatihan meliputi petunjuk teknis perilaku yang baik bagi penderita dan anggota keluarga untuk mencegah penularan TB dalam keluarga. Selain itu diberikan pelatihan tentang petunjuk teknis mewujudkan rumah sehat bagi masyarakat, terutama yang berdekatan dengan penderita TB. Dengan adanya pelatihan, besar harapannya masyarakat dapat memiliki pengetahuan tentang apa itu penyakit TB. Tidak hanya itu, selain ceramah dan pelatihan, metode yang dilakukan juga diselingi dengan diskusi dan tanya jawab sebagai bentuk timbal balik agar tidak terkesan monoton. Pada kesempatan ini peserta dapat mengeluarkan pertanyaan dan secara bersama mendiskusikan jawaban dari pertanyaan tersebut.

Penyuluhan dan Pelatihan bagi warga dilaksanakan pada hari Sabtu tanggal 7 Juli 2018 pada jam 19.30-22.00 WIB di lokasi rumah Ketua RT 09 Dusun X. kegiatan kedua yaitu Analisis Kondisi Kesehatan Lingkungan Rumah dan Pelatihan bagi keluarga penderita TB untuk mencegah penularan dilaksanakan hari Minggu tanggal 8 Juli 2018 pada jam 08.00 - 12.00 WIB dengan lokasi rumah Warga penderita TB. Sasaran kegiatan penyuluhan dan pelatihan adalah seluruh warga Dususn X RT 09, Banguntapan, Bantul, Yogyakarta sebayak $63 \mathrm{KK}$. Sampel yag diambil dalam penelitian ini sebanyak 21 KK yag ditentukan melalui kelompok pengambilan data saat melakukan community diagnostik. 
Untuk kegiatan analisis, ditujukan kepada penderita TB dan anggota keluarga penderita TB di Dusun X RT 09.

\section{HASIL DAN PEMBAHASAN}

\section{Analisis Kondisi Kesehatan Lingkungan Rumah}

Berdasarkan hasil pendataan dengan menggunakan instrument Program Indonesia Sehat Pendekatan Keluarga (PIS-PK) yang dilakukan di Dusun X RT 09 didapatkan hasil bahwa terdapat salah satu keluarga yang memiliki penyakit Tuberkulosis (TB). Tuberkulosis merupakan penyakit yang dapat menular dengan cara yang sangat mudah, sehingga permasalahan Tuberkulosis tersebut menjadi prioritas utama yang harus lebih diperhatikan dan diatasi.

Pemingkatan kasus Tuberkulosis paru dapat dipengaruhi oleh beberapa faktor, diantaranya adalah kondisi fisik lingkungan rumah. Kualitas lingkungan fisik rumah yang tidak sehat memegang peranan penting dalam penularan dan perkembagbiakan Mycobacterium Tuberculosis. Kurangnya sinar matahari yang masuk ke dalam rumah, ventilasi yang buruk cenderung menciptakan suasana yag lembab dan gelap, kondisi ini menyebabkan kuman dapat bertahan berhari-hari sampai berbulan-bulan di dalam rumah (Kandau \& Posangi, 2015).

Tabel 1. Data pengukuran ruang keluarga penderita TB

\begin{tabular}{lll}
\hline Indikator & Ruang Keluarga (A) & Ruang Keluarga (B) \\
\hline Kelembaban & $72 \%$ & $75 \%$ \\
\hline Pencahayaan & 3 lux & 24 lux \\
\hline Suhu & $33^{\circ} \mathrm{C}$ & $33^{\circ} \mathrm{C}$ \\
\hline
\end{tabular}

Berdasarkan pengamatan yang dilakukan di lingkungan rumah penderia $\mathrm{TB}$, didapatkan hasil bahwa pengkuran kelembaban di dalam rumah informan yaitu di ruang keluarga A sebesar $72 \%$ dan di ruang keluarga B sebesar 75\%, sedangkan persyaratan kesehatan rumah tinggal menurut Keputusan Menteri Kesehatan RI Nomor : 829/Menkes/SK/VII/1999 yaitu kelembaban udara antara 40-70\%. Jika dibandingkan rumah penderita TB dengan persyaratan kesehatan rumah tinggal menurut Keputusan Menteri Kesehatan bahwa rumah tersebut termasuk dalam kategori rumah yang tidak sehat.

Pengkuran pencahayaan didalam rumah informan pada ruang keluarga A sebesar 3 Lux dan ruang keluarga B sebesar 24 Lux, sedangkan persyaratan kesehatan rumah tinggal menurut Keputusan Menteri Kesehatan RI Nomor: 829/Menkes/SK/VII/1999 adalah sebagai berikut : Pencahayaan alam atau buatan langsung atau tidak langsung dapat menerangi seluruh bagian ruangan minimal intensitasnya 60 lux dan tidak menyilaukan. Jika dibandingkan rumah informan dengan persyaratan kesehatan rumah tinggal menurut Keputusan Menteri Kesehatan bahwa rumah tersebut termasuk dalam kategori rumah yang tidak sehat (Kemenkes RI, 1999).

Ventilasi didalam rumah informan kurang dari 10\% dari luas lantai, sedangkan persyaratan kesehatan rumah tinggal menurut Keputusan Menteri Kesehatan RI Nomor : 829/Menkes/SK/VII/1999 yaitu luas penghawaan atau ventilasi yang permanen minimal 
adalah $10 \%$ dari luas lantai. Ventilasi berfungsi untuk menjaga agar udara didalam rumah tetap segar, membebaskan udara ruangan dari bakteri-bakteri pathogen. Kurangnya venilasi akan menyebabkan kurangnya kadar oksigen, bertambahnya kelembaban udara di dalam ruangan (Kemenkes RI, 1999).

Di dalam rumah tersebut terdapat dua keluarga yang berjumlah 6 orang, dengan luas rumah sebesar $21 \times 11 \mathrm{~m}$, terdapat 2 kamar tidur, 1 kamar mandi, dan ruang keluarga yang sekaligus dijadikan sebagai tempat garasi motor. Menurut Keputusan Menteri Kesehatan Republik Indonesia Nomor 829/Menkes/SK/VII/1999 yaitu luas ruang tidur memenuhi syarat bila luas kamar tidur minimal 8 meter, dan tidak dianjurkan digunakan lebih dari 2 orang tidur didalam satu ruang tidur, kecuali anak dibawah usia 5 tahun (Kemenkes RI, 1999). Jika dibandingkan rumah informan dengan persyaratan kesehatan rumah tinggal menurut Keputusan Menteri Kesehatan bahwa rumah tersebut termasuk dalam kategori rumah yang tidak sehat.

\section{Pelatihan Pengelolaan lingkungan dan Rumah Sehat}

Kelembaban, pencahayaan, ventilasi, kepadatan hunian dari rumah penderita TB menurut Keputusan Menteri Kesehatan Republik Indonesia Nomor 829/Menkes/SK/VII/1999 tidak memenuhi sarat rumah sehat. Berdasarkan hal tersebut, maka dilakukan pelatihan kepada penderita TB dan keluarganya untuk mencegah adanya penularan yang lebih luas karena kondisi rumah yang tidak mendukung.

Pengukuran kelembaban ini dilakukan di ruang keluarga dengan menggunakan alat ukur Hygrometer. Pada pengamatan ini diketahui bahwa kelembaban yang tinggi disebabkan karena beberapa factor seperti kurangnya cahaya yang masuk kedalam rumah, jenis lantai, jenis dinding, dan ventilasi, sehingga dapat menyebabkan tingginya kelembaban pada ruangan. Pelatihan yang diberikan berupa upaya untuk membuat rumah tidak lembab yaitu dengan membuka candela dan pintu lebar-lebar di pagi hari.

Kelembaban yang tinggi di dalam rumah akan mempermudah berkembang biaknya mikroorganisme antara lain bakteri spiroket, ricketsia dan virus. Mikroorgaisme tersebut dapat masuk ke dalam tubuh melalui udara, selain itu kelembaban yag tinggi dapat menyebakan membra mukosa hidung menjadi kering sehingga kurang efektif dalam menghadang mikroorganisme. Sifat kuman Tuberkulosis mampu bertahan hidup di tempat gelap dan lembab selama berbulan-bulan, namun tidak taha terhadap sinar matahari atau aliran udara (penghawaan) (Kandau \& Posangi, 2015).

Hasil penelitian yang didapatkan pada rumah informan sesuai dengan hasil penelitian sebelumnya menunjukkan bahwa ada hubungan yang bermakna antara kelembaban dengan kejadian tuberculosis paru (Hartono, 2004). Serta penelitian ini sesuai dengan teori bahwa ruangan rumah perlu dijaga kelembabannya. Ruangan rumah yang lembab akan meningkatkan perkembangan mikroorganisme termasuk kuman Mycobakterium tuberkulosis. Penelitian lain yang lain juga menunjukan hasil yang menyatakan ada hubungan antara kelembaban dengan kejadian TB paru (Sugiarto, 2003).

Komponen yang harus dimiliki rumah sehat salah satunya adalah dinding rumah yang kedap air yang berfungsi menyangga dan menahan atap, menahan air dan air hujan, melindungi panas dan debu dari luar, serta menjaga kerahasiaan penghuninya. Hasil ini sejalan dengan penelitian Anggie Mareta yang menyatakan bahwa orang yang tinggal di 
dalam rumah dengan tingkat kelembapan yang tidak memenuhi syarat memiliki risiko 4.033 kali lebih besar untuk menjadi sakit TB (Rosiana, 2013).
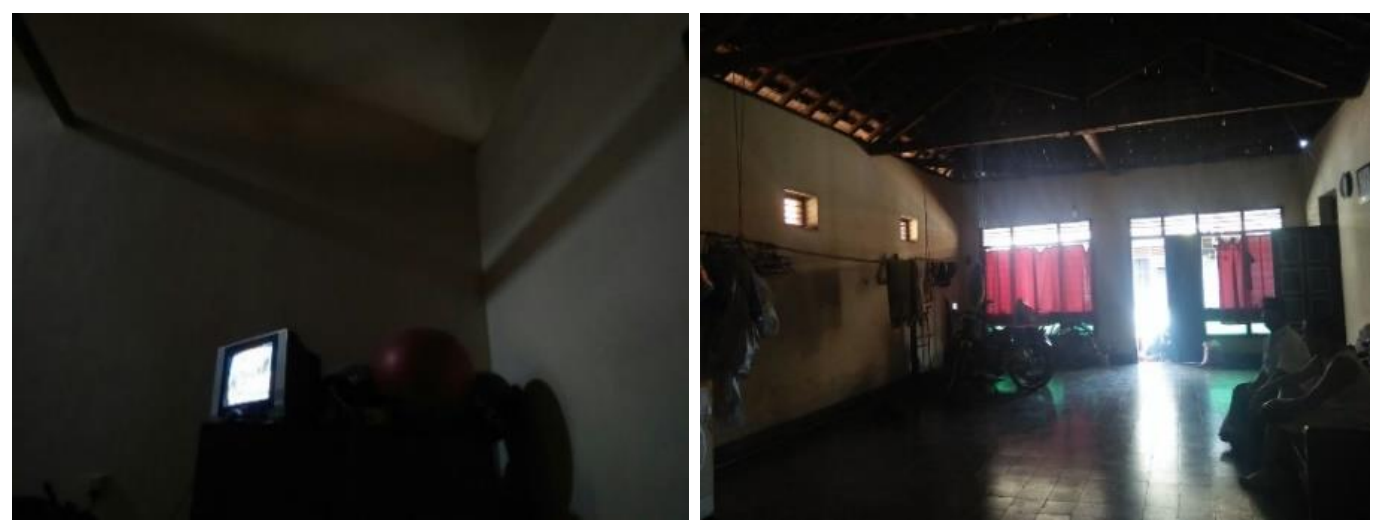

Gambar 1. Pencahayaan Ruang Keluarga Penderita TB

Pengukuran pencahayaan dilakukan di ruang keluarga dan pencahayaan yang digunakan pada saat pengamatan ini dilakukan yaitu pencahayaan alami matahari, karena penelitian ini dilaksanakan pada pagi hingga siang hari. Pada pengamatan ini diketahui bahwa pencahayaan yang kurang disebabkan karena kurangnya kesadaran informan yang tidak membuka jendela, gorden, dan pintu rumah. Kurangnya kaca pada atap rumah juga dapat mempengaruhi banyaknya sinar matahari yang masuk kedalam rumah. Sinar matahari juga tidak dapat masuk karena terhalang oleh dinding atau tembok rumah para tetangga lainnya sehingga tidak dapat mengenai ruangan di dalam rumah informan. Penghuni rumah diberi informasi sekaligus mempraktekan membuka candela, gorden dan pintu rumah.

Hasil observasi yang didapatkan pada rumah penderita TB sejalan dengan penelitian sebelumnya menyatakan bahwa ada hubungan pencahayaan dengan kejadian TB Paru. Berdasarkan hasil pengamatan di rumah informan didapatkan pula hasil bahwa luas ventilasi rumah responden tidak memenuhi syarat (Wulandari, 2012). Hal ini dikarenakan ventilasi yang ada dirumah informan tidak digunakan dengan semestinya, misalnya jendela yang dibiarkan selalu terutup dan tidak dibiasakan untuk membuka jendela setiap pagi, sehingga sebagian besar jendela pada rumah informan bukan termasuk ventilasi dan sebagian besar ventilasi belum memenuhi syarat yaitu $10 \%$ dari luas lantai (Wulandari, 2012).

Hasil penelitian sebelumnya menunjukkan ada hubungan yang bermakna antara luas ventilasi dengan kejadian tuberculosis paru. Ventilasi merupakan faktor risiko terjadinya penyakit TB Paru, resiko untuk menderita TB Paru 5 kali lebih tinggi pada penduduk yang tinggal pada rumah yang ventilasinya tidak memenuhi syarat kesehatan. Ventilasi yang tidak baik dapat menyebabkan udara tidak nyaman (kepengapan, bronchitis, asma kambuh, masuk angin) dan udara kotor (penularan penyakit saluran pernafasan), dan ventilasi yang baik harus memenuhi persyaratan agar udara yang masuk tidak terlalu deras atau terlalu sedikit, luas ventilasi minimal $10 \%$ dari luas lantai.(7) Depkes RI mensyaratkan untuk luas lubang ventilasi tetap minimum $10 \%$ dari luas lantai ruangan, sedangkan luas lubang ventilasi yang tidak tetap (dapat dibuka dan ditutup) 10\% dari luas lantai (Kemenkes RI, 1999). 


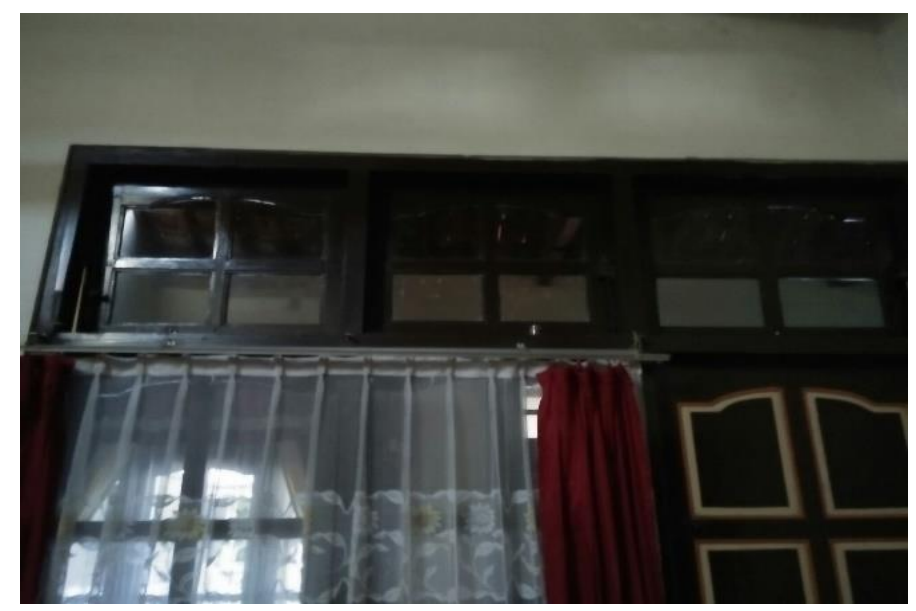

Gambar 2. Kondisi Ventilasi Rumah Penderita TB

Pengaruh buruk berkurangnya ventilasi adalah berkurangnya kadar oksigen, bertambahnya kadar gas $\mathrm{CO} 2$, adanya bau pengap, suhu udara naik, dan kelembaban udara ruangan udara bertambah (Mukono, 2000). Hal tersebut menjadi salah satu faktor risiko terjadinya TB karena bakteri tuberculosis dapat bertahan hidup dalam waktu lama ditempat yang gelap dan lembab (Erlien, 2008)

Dalam ruangan tertutup yang terdapat banyak manusia, kelembaban akan lebih tinggi jika dibandingkan di luar ruangan. Oleh karena kelembaban memiliki peran bagi pertumbuhan mikroorganisme termasuk bakteri tuberkulosis (TB), dengan kepadatan hunian yang terlalu padat secara tidak langsung juga mengakibatkan penyakit tuberkulosis (TB) paru. Jumlah penghuni yang padat juga memungkinkan kontak yang lebih sering antara penderita TB paru dengan anggota keluarga lainnya sehingga mempercepat penularan penyakit tersebut. Pada penderita dan keluarganya diberi pelatihan tentang bagaimana menutup muka dengan masker bagi penderita, cuci tangan, membuang dahak dan bagaimana meningkatkan hygiene perorangan.

\section{Penyuluhan tentang TB, Pencegahan dan Penanggulangannya}

Perubahan perilaku dan persepsi individu dapat dilakukan dengan penyuluhan kesehatan dengan menggukan pendekatan model Health Belief Model (HBM). Model HBM dipengaruhi oleh faktor modifikasi seperti usia, jenis kelamin, budaya, ras, psikologis, sosial ekonomi, teman, kelompok pendidikan dan pengetahuan yang ada pada individu. Persepsi individu dalam memandang penyakit dipengaruhi oleh tindakan yang dilakukan seperti adanya penyuluhan kesehatan melalui media massa, koran, majalah, ceramah, nasehat dari orang terdekat, adanya kartu pengingat, faktor penyakit yang dialami oleh anggota keluarga juga dapat memengaruhi persepsi individu dalam memandang penyakitnya sebagai ancaman.

Berdasarkan Undang-Undang Republik Indonesia No. 23 Tahun 1992, pasal 38, ayat 1 menyebutkan; penyuluhan kesehatan masyarakat merupakan kegiatan yang melekat pada setiap kegiatan upaya kesehatan. Penyuluhan kesehatan masyarakat diselenggarakan untuk mengubah perilaku seseorang atau kelompok masyarakat agar hidup sehat melalui komunikasi, informasi, dan edukasi. Penyuluhan kesehatan bertujuan untuk memberdayakan individu, kelompok dan masyarakat dalam memelihara, meningkatkan dan melindungi kesehatan, melalui peningkatan 
pengetahuan, kemauan dan kemampuan, serta mengembangkan iklim yang mendukung, yang dilakukan dari, oleh dan untuk masyarakat, sesuai dengan sosial budaya dan kondisi setempat.

Faktor perilaku penderita ikut menentukan dalam keberhasilan pemberantasan TB paru. Salah satu faktor yang menentukan penderita untuk taat berobat dan taat minum obat secara teratur dan tuntas antara lain faktor pengetahuan tentang pencegahan dan pengobatan TB paru. Untuk meningkatkan pengetahuan masyarakat dan penderitaTB paru tentang pencegahan dan pengobatan TB perlu dilauka pemberian informasi (penyuluhan) denga metode dua arah denga harapan akan meningkatka pengetahua masyarakat dan penderita TB (Sukana, Herryanto, \& Supraptini, 2003).

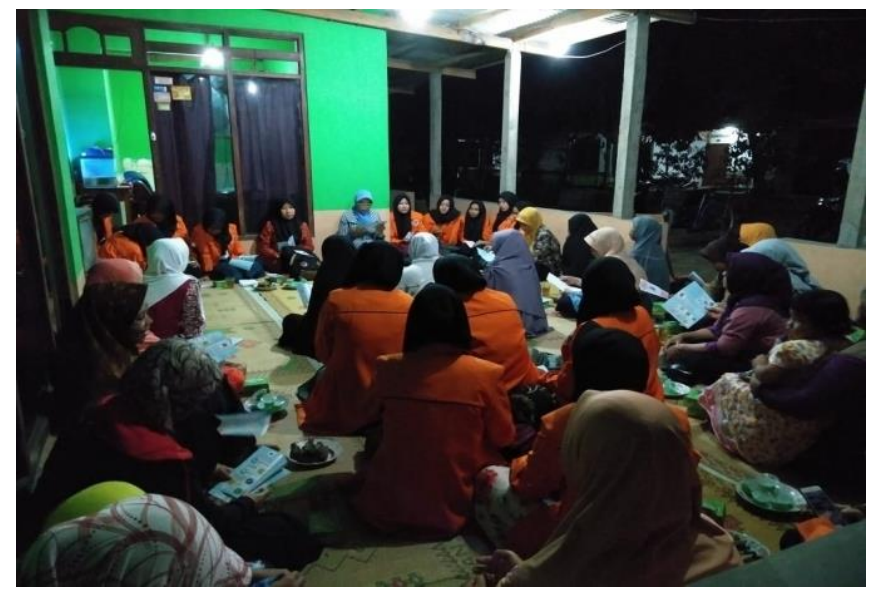

Gambar 3. Penyuluhan tentang TB

Masalah utama yang terdapat di RT 09 yaitu Tuberkulosis, maka dilakukan upaya pencegahan dan pengendalian tuberkulosis dengan cara melakukan penyuluhan menggunakan metode ceramah dan tanya jawab terhadap warga RT 09 di Dusun X, Banguntapan, Bantul. Materi penyuluhan yang disampaikan pada saat intervensi, yaitu materi terkait tuberkulosis diantaranya definisi tuberkulosis, cara penularan, cara pencegahan, gejala-gejala tuberkulosis, pemeriksaan dan pengobatan tuberkulosis.

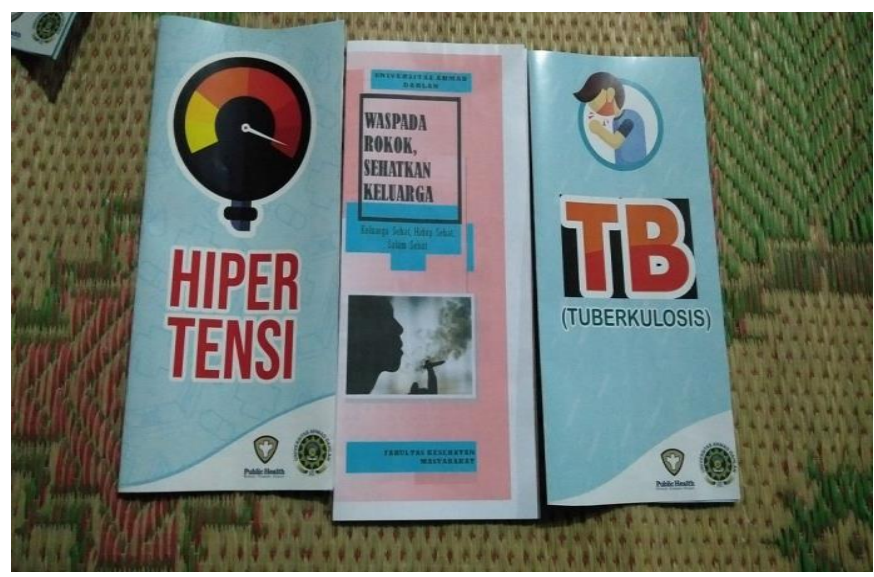

Gambar 4. Leaflet Penyuluhan Dusun X RT 09 
Media yang digunakan pada saat intervensi berlangsung yaitu leaflet. Hal ini dikarenakan leaflet cukup mudah dibuat, praktis dan dapat dibawa kemanapun dengan mudah.

\section{SIMPULAN}

Penyakit Tuberkulosis dipilih sebagai tema Intervensi kepada masyarakat yang diberikan di Dusun X RT 09. Keputusan tersebut didasarkan kepada hasil yang diperoleh dari community diagnosis di lokasi bahwa ditemukan satu penderita TB dan memiliki resiko tinggi menularkan kepada keluarga dan masyarakat sekitarnya. Hasil dari program pengabdian masyarakat ini diharapkan dapat mencegah dan mengatasi penularan penyakit TB di lingkungan rumah tempat tinggal.

\section{REFERENSI}

Dinas Kesehatan DI Yogyakarta. (2013). Profil kesehatan Daerah Istimewa Yogyakarta 2013. Health Care, 8(6), 719-727. doi: 10.1017/CBO9781107415324.00.

Dinkes Kabupaten Bantul. (2016). Profil Desa Jambidan. Retrieved July 10, 2018 from www.jambidan.bantulkab.go.id.

Erlien, T. (2008). Penyakit saluran pernapasan. Jakarta: Sunda Kelapa Pustaka.

Hartono, E. (2004). Hubungan kondisi fisik rumah dengan kejadian penyakit TB paru di wilayah kerja Puskesmas Pekuncen Kecamatan Pekuncen Kabupaten Banyumas tahun 2004 (Skripsi). Universitas Diponegoro, Purwokerto, Indonesia.

Kandau, G. D., \& Posangi, J. (2015). Hubungan kualitas lingkungan fisik rumah dengan kejadian tuberkulosis paru di wilayah kerja puskesmas perawatan Siko Kecamatan Ternate Utara Kota Ternate Provinsi Maluku Utara. Jurnal e-Biomedik, 3(3), 856-64.

Mukono, H. J. 2000. Prinsip Dasar kesehatan lingkungan. Surabaya: Unair Press.

Rosiana, A. M. (2013). Hubungan antara kondisi fisik rumah dengan kejadian tuberkulosis paru di wilayah kerja Puskesmas Kedungmundu Kota Semarang. Unnes Journal of Public Health, 2(1), 1-9.

Kemenkes RI. (2015). Tuberkulosis temukan obati sampai sembuh. Jakarta: Infodatin Kemenkes RI.

Kemenkes RI. (2017). Profil kesehatan Indonesia tahun 2016. Jakarta: Kemenkes RI.

Kemenkes RI. (1999). Keputusan Menteri Kesehatan RI Nomor: 829/Menkes/SK/VII/1999 tentang Persyaratan Kesehatan Perumahan. Jakarta: Departemen Kesehatan RI.

Sugiarto. S. 2003. Hubungan Kondisi Fisik Rumah Dengan Kejadian Penyakit TB Di Kota Surakarta Tahun 2003 (Skripsi). Universitas Diponegoro, Purwokerto, Indonesia. 
Sukana, B., Herryanto, H., \& Supraptini, S. (2003). Pengaruh penyuluhan terhadap pengetahuan penderita TB paru di kabupaten Tangerang. Jurnal Ekologi Kesehatan, 2(3), 282-289.

Undang-Undang Republik Indonesia No. 23 Tahun 1992 tentang Kesehatan.

Wulandari, S. (2012). Hubungan lingkungan fisik rumah dengan kejadian tuberkulosis paru. Unnes Journal of Public Health, 1(1), 41-44. 